\title{
Mars, Venus and Gray: Gender Communication
}

\author{
Dr Kamarul Zaman Ahmad (corresponding author) \\ Faculty of Business \& Accountancy, University of Malaya \\ Kuala Lumpur, Malaysia \\ E-mail: drkamphd@yahoo.com, Website: http://www.drkamphd.com \\ Kalaiselvi Rethinam \\ University of Malaya, Kuala Lumpur, Malaysia \\ E-mail:kzahmad@um.edu.my
}

\begin{abstract}
This research tests the propositions relating to gender communication by Gray (1992) in his book titled "Men are from Mars, Women are from Venus" which had remarkable similarities with Tannen's (1990) research. It would be interesting to find out whether Gray's statements about gender differences in communication can be supported by an empirical study conducted in Malaysia. The sample consisted of 182 executives and non-executives (73 males and 109 females). T-test results show that out of 23 statements made by Gray (1992), only 8 were supported, 10 were not supported and 5 were actually true for the opposite gender. The implication of this is that one should be very careful when using Grays (1992) book as a guide to gender-related communication in Malaysia.
\end{abstract}

Keywords: Gender, Communication, John Gray, Mars and Venus

\section{Introduction}

The idea that women and men have different communication styles have become the theme of many best-selling books on gender differences such as the book written by Gray (1992) titled "Men are from Mars, Women are from Venus". This book argues that there are significant and consistent differences in communication styles between men and women. The book by Gray (1992) was written for the layperson and is a popular book bought by the general public worldwide. However, Gray (1992) did not state in his book, whether he had conducted any empirical research. It is also interesting to note that Gray's (1992) book came out two years after the publication of Tannen's (1990) research. Gray's (1992) book was intended to improve communication between men and women in the workplace so that they would understand each other better and able to reduce the communication gap which would otherwise result in increased job satisfaction and productivity. Gray (1992) proposed that there are universal differences between men and women when it comes to communication. The study therefore aims to assess whether there are consistent gender differences in communication styles, as mentioned by Gray (1992).

An important justification for this research is that Gray (1992) himself did not claim to have conducted any scientific research and his pronouncements are based purely on theory and not supported by empirical research (Wood and Dindia, 1998). In fact, Gray's statements are often contradicted by the findings of many respected scholars, mentioned in the literature review. Thus, the main objective of this research is to test the propositions that Gray (1992) has made in his book, in the context of Malaysia - a developing country where if such archaic gender stereotypes are true, then it will most likely be found here, as Malaysia is well-known for its high power-distance culture (Hofstede 1980). This research aims to verify whether the propositions stated in the book are accurate explanations for the difficulties in communication and working styles that exist i.e. are the difficulties gender-related or do they exist irrespective of gender? This is the research question that this study aims to address. Differences in communication and working styles can lead to misunderstanding and frustrations between the sexes and may ultimately impact in decision-making in the work place. So it is important to find out whether differences in gender contribute to this problem, or whether such problems occur independently of gender.

\section{Literature Review}

The work place presents an opportunity to observe real interactions between men and women in the context of the many constraints as described by Kendall and Tannen (1997). When people come together in organizations to get things done in a work place, they will need to talk - and talk is the lifeblood of all organizations (Boden, 1994). So, work-related communication plays an important role in organizations. There are several important topics pertaining to the alleged differences in communication and working styles of men and women that were 
highlighted by Gray (1992) which are listed and described below. Other researches that either support or contradict these propositions are also discussed.

\subsection{Working styles and competency evaluation}

Gray (1992) suggested that men prefer to do things by themselves, tend to evaluate the competence of others when interacting and are more competitive. This is somewhat consistent with some research that have shown that men tend to value male input over female input and assume that men are more competent than women (Martin, 1996; Pierce, 1995; Williams, 1995). Males are also more likely than females to intentionally withhold information to further their own positions or harm another's position (Deal, 2000). Such ways that men accomplish something have often identified them as being competent, but this is not the case when it comes to women. Men trust more than women, and women are more trustworthy than men (Buchan,Croson \& Solnick, 2008). However, conversation style differences frequently lead to women being evaluated as less competent than men. Men or also known as Martians by Gray (1992) value power, competency, efficiency, action, achievement, and accomplishment. His view on women's (he calls them "Venusians") sense of self in the work place is defined primarily by the quality of her work relationships. In the work place, Venusians respect efficiency and achievement, but values support, trust, and communication more. He also claimed that Venusians are more interested in the quality of work relationships, personal expression, and mutual support than Martians. Venusians experience fulfillment by sharing, collaborating, and cooperating in the process of achieving greater success.

Gray's (1992) attitudes and support of traditional, power-based relationships is evident in his writing. He states that women, are completely at the mercy of their hormones and feel no connection between self-esteem and their own accomplishments. "A woman's self-esteem generally rises and falls in a cycle not necessarily in sync with her menstrual cycle, but it does average out at twenty-eight days" (p. 21). Men, on the other hand, "value power, competency, efficiency and achievement" (Gray 1992: 16). Women who go out of home to work, "put on the Martian suits" and leave behind daily tasks such as housework and childcare that are their primary responsibility. Men are encouraged to help with domestic tasks on an occasional basis strictly as a method of "keeping her love tank full and the score even" (Gray 1992: 186). Similarly, in a study on married couples and couples living together, it was found that women compared with men, wanted greater increases in their partners' emotional and companionate behaviors, instrumental support, and parenting involvement whereas men wanted greater increases in sex (Heyman, Hunt-Martorano, Malik, and Slep, 2009).

\subsection{Problems in communication with the opposite gender}

\subsubsection{Asking questions}

Asking questions means different things to men and women, and thus the complexity underpinning the significance of asking questions is often managed in different ways. According to Tannen (1994), the language of conversation is primarily a language of rapport for women i.e. a way of establishing connections and negotiating relationships. For men, talk is primarily a means to provide information, preserve independence and negotiate and maintain status in a hierarchical social order i.e. a language of report. It has also been found that men tend to interrupt more and they are more resistant to asking questions (Tannen, 1990; Coates, 1996; Lackoff, 1990). Women are more likely than men to ask questions and agree with others, and women are less likely than men to challenge others' statements and frame others' arguments. These differences are theorized to reflect women's greater concerns for cooperation and connection in their relationships. These conclusions are consistent with Gray's (1992) notion that men are more likely to interpret messages according to levels of dominance, whereas women are more likely to interpret them according to levels of supportiveness.

\subsubsection{Communication directness and indirectness}

Tannen (1990) describes how, when questioned about why more women were not hired or promoted, male managers used statements about women lacking confidence. One behavior that may be seen by others as a lack of confidence may be the indirect way women give orders. Women often use tagged phrases like "don't you think" following the presentation of an idea, "if you don't mind" following a demand or "this may be a silly idea, but" preceding a suggestion. Several studies have shown that women tend to soften their demands and statements, whereas men tend to be more direct (Coates, 1989; Tannen, 1990; Spender, 1980; Case, 1994). Women have also been persuaded that it is not "businesslike" to complain (Perriton, 2009).

\subsubsection{Trouble Talk}

Tannen (1990) asserts that men are confused by the various ways in which women use conversation to be intimate with others. One of these ways is "trouble talk" i.e. talking about one's troubles or problems. She claims that for women, talking about troubles is the essence of connection. It signifies and creates closeness. Men, 
however, may interpret trouble talk as a request for advice, and thus, could respond with a solution. The impasse that occurs may result in a feeling of weakness by the female, where she may feel cut off and her problem diminished as men tend to provide solutions when women actually needs to talk about her problem to create a relationship. Tannen (1990) went on to argue that, as a consequence of these general differences in communication styles, women and men may tend to choose different behavioral responses (such as giving sympathy and giving advice respectively) when confronted with "trouble talk". Women and men may also interpret and evaluate these behaviors differently, and therefore feel different emotional responses to sympathy and advice. These gender differences can lead to problems and misunderstandings in communication between women and men.

\subsubsection{Conversational topics in communication}

Linguistic variance between men and women take place in the topics they choose to discuss. Women are said to select topics of a more personal type such as their family, their emotions, and their friendships. Besides that, women are not afraid to embed details in their speech in order to involve people in the events being described. Men, however, use more abstract communication, speaking in general terms (Kramarae and Treicher, 1983; Schaef, 1985). Men tend to use linear speech, moving sequentially through points unlike women. Women use a personal style, allowing them to divulge details of experience and personal matters. Linear speech requires less intimacy and also reaffirms the conversational goal as being one of information exchange. Women's conversations focus more on the development and maintenance of conversations and the relationships between the speakers through supportive listening.

\subsubsection{Talk time}

There have been stereotypes of how women and men talk which portray women as talking more than men (Coates, 1996). However, research has shown that men and boys talk more in mixed sex groups than women and girls (Spender, 1980). The studies predominantly show that in a mixed sex conversation, the average amount of time for which a man will talk will be approximately twice as long as the average amount for which a woman will talk. Women may perceive men's conversational dominance as an exercise of power. As a consequence, women who talk for more than one third of the available time may be regarded by others as talking too much.

\section{Other propositions by Gray (1992)}

Gray states that, women continually self-disclose, sharing their "process of inner discovery" (1992: 19) with anyone who will listen, while men quite often stop communicating all together and become silent. A Martian would never "burden" another man with his problems and would rather watch TV or work on his car than discuss his problems with a woman. Gray (1992: 30) states, "Instead he becomes very quiet and goes to his private cave to think about his problem, mulling it over to find a solution. When he has found a solution, he feels much better and comes out of his cave". Tannen (1990) declared that scholars and individuals must acknowledge that men and women communicate differently. Parsons and Bales (1955) described women as expressive and men as instrumental. Gilligan (1982) asserted that women measure everything in terms of relationships and men measure in terms of logic. Gray (1992) may have taken Tannen's (1990) propositions further by declaring that men and women not only communicate differently, but they have so little in common as to be from completely different planets - struggling to comprehend one another. Many gender scholars agree that some differences do exist in men's and women's approaches to relationships (Basow and Rubenfeld, 2003; Cole, 2004; Hekman, 1999; Wood, 1982, 2005). Human communication styles are a social construction which encourages women more and men less, to develop traits that enhance interpersonal problem-based communication (Baird, 1976; Basow and Rubenfeld, 2003). Since Gray's (1992) book was published, the phrase "Men are from Mars, Women are from Venus" has become a metaphor for expressing the notion of gender differences and propagating stereotypes. However, Gray (1992) failed to cite any empirical evidence (as it appears that he has not conducted any scientific research on the topic) to support his theories about specific communication characteristics, and his findings frequently conflict with reputable scholarly research in these areas.

\section{Studies done in other countries}

Studies done outside the U.S.A had some interesting results. For instance, in a study that investigated the communicative strategies used by Japanese males and females in gender-mixed formal interactions, quantitative results show that female and male hosts use polite strategies, but female guests are more assertive than male guests. However, the qualitative results show a much more complex picture; domineering and cooperative strategies are used by both, male and female participants (Tanaka, 2009). In another study conducted among science teachers from secondary schools in Taiwan, it was found that female science teachers perceived greater collegiality among teachers, higher gender equity among students, and stronger professional interest, and male 
science teachers perceived lower work pressure and better teacher-student relations (Huang \& Fraser, 2009). Also, in a study conducted in the three Netherlands schools, it was discovered that female students in the mixed gender groups did not learn to solve physics problems as well as male partners or as female students in all-female dyads. Analyses of interactive behaviours showed that female students in the mixed gender groups devoted less time actively seeking solutions and spent more time asking questions than their male partners. Female students in the all-female dyads did not differ in interactive behaviour or post-test performance from males. They had a more balanced interactive style than females in the mixed-gender dyads (Harskamp, Ding \& Suhre, 2008).

\section{Studies that contradict Gray (1992)}

Gray (1992: 22) writes that men constantly interrupt their partners and offer solutions while "Venusians never offer solutions while someone else is talking". While there are studies that found that men interrupt women more often than women interrupt men, often as a show of power (Berryman-Fink and Brunner, 1987), a meta-analysis of studies on interruptions by Dindia (1987) found that such studies failed to account for the fact that communication behaviour is often interdependent. So those who interrupt may have an effect on their partner's subsequent interrupting behaviour. Dindia (1987) discovered that both sexes interrupt and that men do not interrupt more than women, especially in mixed-sex dyads. Furthermore, women's interruptions are no less assertive than men's interruptions. In fact, Dindia (2006) coined the metaphor, "Men are from North Dakota, women are from South Dakota" in an effort to emphasize that any existent differences between male and female communication practices are not planetary. Dindia and Allen's (1992) meta-analysis on sex differences in self-disclosure concurred with previous findings that women disclose more than men but revealed that this is only true in same-sex dyads. When talking with men, women do not disclose any more than their male partners disclose. Another important point to consider when comparing Gray's work to scholarly findings is that individuals who argue that there are inherently male and female characteristics and behaviors, may be guilty of gender stereotyping (Eisenberg, Martin, and Fabes, 1996). This assumption that certain distinct characteristics are the essence of women while other, different and equally distinct characteristics are the essence of men is known as essentializing (Wood, 1993). Generalized statements that specific characteristics or behaviors are true for all men, while others are true for all women, are based on the idea that behaviour is inherent and constant. Wood (2001) objects to efforts to essentialize women and men, in particular the assertion that communication styles are innate and unchangeable. Essentializing and gender stereotyping leave no room for individuality.

Thus, one cannot ignore the growing body of evidence that contradicts Gray's (1992) propositions. Kim and Bresnahan (1996) examined the determination of intention or motive behind verbal strategy choices and found no significant differences in what men and women perceive as important in communication. The Bem's Sex Role Inventory (Wong, McCreary and Duffy, 1990) argues that men and women can and do develop attributes in both masculine and feminine gender domains. Wood and Dindia (1998) object to the solutions that Gray (1992) prescribes which are a disservice to the women and men who follow them because they are not based on theory supported by empirical research. Murphy (2001) argues that Gray's work provides a "disturbing interpretive framework" ( p. 151) for understanding communication based on a "sexist form of anthropology" (p. 164). Dindia and Allen (1992: 118) conclude that, "it is time to stop perpetuating the myth that there are large differences in men's and women's self-disclosure."

As such, there is a real need and a genuine justification for this research to be conducted in order to test the numerous propositions made by Gray (1992) i.e. are the difficulties gender-related or do they exist irrespective of gender? By doing so, it is hoped that communication and working styles of men and women in organizations can be better understood, coordinated and enhanced, and any gap between men and women can be reduced for a better understanding between the two genders in the work place.

\section{Research Methodology}

\subsection{Sample}

The sample comprised of employees from the headquarters of the Malaysian Postal Services Company or also known as Pos Malaysia Berhad, located in Kuala Lumpur, Malaysia. The reason for selecting a single institution was not only for convenience but also to control for differences in organizational culture, organization size and geographic location. Furthermore, Pos Malaysia Berhad was chosen because like Malaysia, the majority of the people here are of the Malay race.

Negotiations were held with the Human Resource manager on the selection procedure of the participants and it was finally agreed that questionnaires could be sent to 300 employees i.e. 150 executives and 150 non-executives. Also, an equal number of questionnaires were sent to males and females at the executive and 
non-executive levels. Questionnaires were sent to all the 150 executives whose names were provided by the Human Resource manager. The 150 non-executive employees were selected using stratified random sampling to ensure respondents from each of the different levels were chosen, and questionnaires were distributed to them. However, out of the total of 300 questionnaires distributed, only 182 were completed and returned i.e. a response rate of $60.7 \%$.

\subsection{Measures}

The data collection was done through self-administered questionnaires consisting of two parts. Part A comprises of 23 statements related to communication styles adapted from the book "Men are from Mars, Women are from Venus" (Gray, 1992). Examples are, "I appreciate reassurance at stressful times" and "I am very concerned on achieving the bottom line." The main purpose of these questions is to detect whether there are any significant differences between males and female respondents when describing themselves. Part B comprise of questions related to demographics such as gender, age group, marital status, education, ethnicity and job level.

The statements in Parts A and B were translated to the Bahasa Malaysia language as the non-executive respondents in the organization were well-versed in the local language. The questionnaire was translated using the double translation method as used by Chan (1991) as follows: The statements were first translated into the Bahasa Malaysia language. A second independent translator takes the translated version of the questionnaire and independently translates the instrument back to the English language. Then any inconsistencies of meaning, mistranslations, lost words or phrases between the two English versions of the questionnaire and the translated Bahasa Malaysia version were detected and the questionnaire was revised. A pilot test was further done with a sample size of 10 to reveal any undiscovered ambiguities.

\section{Results}

\section{Insert Table 1 Here}

Descriptive analyses of the sample are shown in Table 1. More females completed and returned the questionnaires compared with men - female respondents made up $59.9 \%$ of the overall responses and male respondents made up $40.1 \%$. Regarding ethnicity, the Malay race formed the largest group by taking up $94.0 \%$ of the sample while the Indians made up $4.4 \%$, followed by the Chinese at $1.1 \%$. The remaining $0.5 \%$ was made up by 1 Sikhs employee referred as the 'Other' ethnic group. $54.9 \%$ of the respondents were between 20 to 29 years old, while $25.8 \%$ were between 30 to 39 years old. $13.7 \%$ were from the age group of 40 to 49 years old. Respondents aged more than 50 years old made up the smallest representation at only $5.5 \%$. As for marital status, $57.1 \%$, of the respondents were married and $42.9 \%$ were either single or not married. $42.3 \%$ of the respondents had only secondary school education. $42.3 \%$ of the respondents had Bachelor degrees, $11.5 \%$ had Diplomas and $3.8 \%$ had Postgraduate Degrees. $46.2 \%$ of the respondents were executives while $53.8 \%$ were non-executives.

Insert Table 2

Only 8 out of the 23 statements made by Gray (1992) were supported (see Table 2). Men, prefer to do things by themselves, tend to evaluate the competence of others when interacting, get annoyed with people who let their emotions interfere with their competence, and are very concerned with achieving the bottom line. Women feel as if they are talking to a brick wall when talking to men, admit to having trouble communicating and interpreting messages from the opposite gender, and feel hurt and rejected when a co-worker of the opposite gender grumbles in response to their request about something.

\section{Insert Table 3}

An amazing 10 out of 23 statements made in Gray (1992) about men and women were not supported (see Table 3). This questions the utility of using Gray's (1992) book as a guide to understanding the so-called differences in communication between the two genders.

\section{Insert Table 4 here}

Table 4 shows what is probably one of the most startling findings in this study -5 out of 23 of the statements made in Gray (1992) were not only unsupported but were actually more true for the opposite gender. Men and not women actually admitted that if they had personal problems, they had to watch themselves carefully so that they don't interfere with their work, unresolved conflict makes them feel very uncomfortable, and if someone appears to be upset, they'll find an opportunity to talk about it with them. Men also feel that if they are unsure of something at work, they will seek advice or assistance and they appreciate reassurance at stressful times. So it appears that Malaysian men have more of such fragile and emotional characteristics and sensitive feelings, compared with Malaysian women. 
Thus a total of 15 out of 23 of the statements pertaining to gender communication made in Gray (1992) were not supported. This questions the much-touted value of using Gray’s (1992) book as a guide to understanding communication coming from different genders in Malaysia - it is not only misleading, but downright dangerous. Based on the results, it would therefore not seem appropriate to recommend readers to use the book as a guide to gender-related communication among Malaysian Malays.

\section{Conclusion}

The objective of this research was to investigate whether there are differences in communication and behaviour of men and women as that propagated by Gray (1992). Overall, the results were not supportive of the propositions by Gray (1992). In Part A of the questionnaire, out of the 23 statements made by Gray (1992), only 8 were supported, 10 were not supported and 5 were actually in the opposite direction (i.e. the statements made by Gray about men were actually more true about women and vice versa). This indeed casts great doubt about the often touted usefulness of reading Gray's (1992) book. The fact that there are centers set up around the world teaching people the principles and tactics advocated in the book is indeed disturbing, as this research has shown that most of his statements are unsupported.

In conclusion, this research is indeed timely in that it addresses the long disservice to women and we need to stop perpetuating the myth that there are large differences in communication between men and women. In particular, it is critical to understand that even if there are average tendencies in the ways men and women communicate, these generalizations certainly do not apply to all men and all women. There are certainly some men who would fit the communication characteristics described here as common to women, and there are certainly some women who would fit the characteristics described here as common to men. It may be more useful to appreciate that different people may have different ways of communicating than to assume that all women communicate one way and all men communicate in another way. There are different styles of communication and most of these differences are independent of gender. So the way forward into the future would be to train people on how to communicate better by making them aware that different people have different preferences and styles of communication. The emphasis should be to match the correct communication style with the individual preference and needs of the audience or listener, rather than essentializing and gender-stereotyping.

\section{Limitations}

As with all research, this one is also not without limitations. Small sample size, one organization, limited geographic location and the fact that most of the respondents are of the Malay race are the obvious limitations. However, despite these limitations, this research is indeed timely as the debate about the existence of so-called gender differences has gone on long enough. Furthermore, it is not the intent of this research to generalize beyond the sample. Rather, its intent is to show that what has been believed by so many people around the world is certainly not true for this sample of post office workers in Malaysia. It is hoped that this research will be the catalyst for many further replication studies all over the world, so that a bigger and better picture can be seen.

\section{References}

Baird, J. E., Jr. (1976). Sex differences in group communication: A review of relevant research. Quarterly Journal of Speech, 62, 179-192.

Basow, S. A. \& Rubenfeld, K. (2003). “Troubles talk”: Effects of gender and gender typing. Sex Roles, 48(3/4), 183-187.

Berryman-Fink, C. \& Brunner, C. C. (1987). The effects of sex of source and target on interpersonal conflict management styles. Southern Speech Communication Journal, 53, 38-48.

Boden, D. (1994). The Business of Talk: Organizations in Action, Polity Press, London.

Buchan, N. R. Croson, R. T. A. \& Solnick, S. (2008). Trust and gender: An examination of behavior and beliefs in the Investment Game. Journal Of Economic Behavior \& Organization, 68(3-4), 466-476.

Case, S. (1994). "Gender differences in communications and behaviour in organisations". In Davidson, M.J., Burke, R.J. (Eds.), Women in Management: Current Research Issues, (pp.144-63) Paul Chapman Publishing, London.

Chan, D. W. (1991). The Beck Depression Inventory: What difference does the Chinese version make? $A$ Journal of Consulting and Clinical Psychology, 3(4), 616-622.

Coates, J. (1989). Women's speech, women's strength? York Papers in Linguistics, 13, 65-76. 
Coates, J. (1996). Women Talk; Conversation Between Women Friends. Blackwell: Oxford.Cole, N. D. (2004). Gender differences in perceived disciplinary fairness. Gender, Work and Organization, 11(3), 254-279.

Deal, J. J. (2000). Gender differences in the intentional use of information in competitive negotiations. Small Group Research, 31, 702-23.

Dindia, K. (1987). The effects of sex of subject and sex of partner on interruptions. Human Communication Research, 13, 345-371.

Dindia, K. (2006). Men are from North Dakota, women are from South Dakota. In K. Dindia \& D.J. Canary (Eds.), Sex differences and similarities in communication, 2nd edition (pp. 3- 20). Mahwah, NJ: Lawrence Erlbaum Associates.

Dindia, K. \& Allen, M. (1992). Sex differences in self-disclosure: A meta analysis. Psychological Bulletin, 112 , 106-124.

Eisenberg, N., Martin, C. \& Fabes, R. (1996). Gender development and gender effects. In D. Berliner \& R. Calfee (Eds.), Handbook of educational psychology (pp. 358-396). New York: Prentice-Hall.

Gilligan, C. (1982). In a different voice. Cambridge, MA: Harvard University Press.

Gray, J. (1992). Men are from Mars and women are from Venus: A practical guide for improving communication and getting what you want in your relationship. New York: Harper Collins.

Harskamp, E., Ding, N. \& Suhre, C. (2008). Group composition and its effect on female and male problem-solving in science education. Educational Research, 50(4), 307-318.

Hekman, S.J. (1999). The future of differences: Truth and method in feminist theory. Cambridge, UK: Polity Press.

Heyman, R. E., Hunt-Martorano, A. N., Malik, J. \& Slep, A. M. S. (2009). Desired Change in Couples: Gender Differences and Effects on Communication. Journal Of Family Psychology, 23(4), 474-484.

Hofstede, G. (1980). Motivation, Leadership, and Organizations: Do American Theories Apply Abroad? Organizational Dynamics, 42-63.

Huang, S. Y. L. \& Fraser, B. J. (2009). Science Teachers' Perceptions of the School Environment: Gender Differences. Journal of Research in Science Teaching, 46(4), 404-420.

Kendall, S. \& Tannen, D. (1997), "Gender and language in the workplace." In Kotthoff, H., Wodak, R. (Eds), Communicating Gender in Context, Benjamins, Amsterdam.

Kim, M-S. \& Bresnahan, M. (1996). Cognitive basis of gender communication: A cross-cultural investigation of perceived constraints in requesting. Communication Quarterly, 44(1), 53-69.

Kramarae, \& Treicher (1983). Gender, language and the workplace: an exploratory study. Women in Management Review, 22(4), 319-336.

Lakoff, G. \& Johnson, M. (1990). Metaphors we live by. Chicago: University of Chicago Press.

Martin, P. Y. (1996). Men, masculinities and management: Gendering and evaluating dynamics. In D. L. Collinson, \& J. Hearn (Eds.), Men as managers, managers as men: Critical perspectives on masculinity (pp. 186-209). London: Sage, Ltd.

Murphy, K. (2001). What does John Gray have to say to feminism? Continuum: journal of media \& cultural studies, 15(2), 159-167.

Parsons, T. \& Bales, R.F. (1955). Family, socialization, and interaction process. Glencoe, IL: Free Press.

Perriton, L. (2009). "We Don't Want Complaining Women!" A Critical Analysis of the Business Case for Diversity. Management Communication Quarterly, 23(2), 218-243.

Pierce, J. L. (1995). Gender trials: Emotional lives in contemporary law firms. Berkeley, CA: University of California Press.

Schaef, A. (1985). Women's Reality: An Emerging Female System in a White Male Society, Harper \& Row, San Francisco, CA.

Spender, D. (1980). Man Made Language, Routledge and Kegan Paul Ltd., London.

Tanaka, L. (2009). Communicative stances in Japanese interviews: Gender differences in formal interactions. Language \& Communication, 29(4), 366-382. 
Tannen, D. (1990). You Just Don't Understand: Women and Men in Conversation. New York: William Morrow. Williams, C. L. (1995). Still a man's world. Berkeley, CA: University of California.

Wong, F.Y., McCreary, D. R. \& Duffy, K. G. (1990). A further validation of the Bem sex role inventory: A multitrait-multimethod study. Sex Roles, 22(3/4), 249-259.

Wood \& Dindia. (1998). What's the difference? A dialogue about differences and similarities between men and women. Mahwah, NJ: Lawrence Erlbaum Associates.

Wood. (1982). Human communication: A symbolic interactionist perspective. New York: Holt, Rinehart, and Winston.

Wood. (1993). Gender and moral voice: From woman's nature to standpoint theory.Women's Studies in Communication, 15, 1-24.

Wood. (2001). A critical response to John Gray's Mars and Venus portrayals of men and women. The Southern Communication Journal, 67(2). 201-211.

Wood. (2005). Gendered lives. Belmont, CA: Wadsworth/Thomson Learning.

Table 1. Descriptive statistic

\begin{tabular}{|c|c|c|}
\hline & & $\%$ \\
\hline \multirow[t]{2}{*}{ Gender } & Male & 40.1 \\
\hline & Female & 59.9 \\
\hline \multirow[t]{4}{*}{ Age group } & 20-29 years & 54.9 \\
\hline & $30-39$ years & 25.8 \\
\hline & $40-49$ years & 13.7 \\
\hline & $>50$ & 5.5 \\
\hline \multirow[t]{2}{*}{ Marital Status } & Single & 42.9 \\
\hline & Married & 57.1 \\
\hline \multirow[t]{4}{*}{ Education } & Secondary School & 42.3 \\
\hline & Diploma & 11.5 \\
\hline & Bachelor Degree & 42.3 \\
\hline & Postgraduate & 3.9 \\
\hline \multirow[t]{4}{*}{ Ethnicity } & Malay & 94.0 \\
\hline & Indian & 4.4 \\
\hline & Chinese & 1.1 \\
\hline & Others & 0.5 \\
\hline \multirow[t]{2}{*}{ Job Level } & Executive & 46.2 \\
\hline & Non Executive & 53.8 \\
\hline
\end{tabular}


Table 2. Independent Samples T-tests from Part A (i.e. statements regarding the respondents themselves) where significant differences between male and female were found thus supporting Gray's (1992) propositions

\begin{tabular}{|c|c|c|c|c|c|c|}
\hline Code & Statements & Mean & Male & Female & Sig & Validation \\
\hline A1 & I like to do things by myself. & 5.24 & 6.06 & 4.39 & 0.00 & Supports Gray \\
\hline A2 & $\begin{array}{l}\text { I always evaluate the competence } \\
\text { of others when interacting. }\end{array}$ & 5.59 & 6.18 & 5.09 & 0.00 & Supports Gray \\
\hline A12 & $\begin{array}{l}\text { I get annoyed with people who let } \\
\text { their emotions interfere with their } \\
\text { competence. }\end{array}$ & 6.36 & 6.84 & 5.78 & 0.02 & Supports Gray \\
\hline A18 & $\begin{array}{l}\text { I am very concern with achieving } \\
\text { the bottom line. }\end{array}$ & 6.29 & 7.02 & 5.60 & 0.00 & Supports Gray \\
\hline A20 & $\begin{array}{l}\text { When I am talking to co-worker } \\
\text { of the opposite gender, I feel that } \\
\text { I am talking to a brick wall. }\end{array}$ & 4.14 & 3.37 & 4.87 & 0.00 & Supports Gray \\
\hline A21 & $\begin{array}{l}\text { I have trouble communicating } \\
\text { with co-worker of the opposite } \\
\text { gender. }\end{array}$ & 4.16 & 3.58 & 4.78 & 0.00 & Supports Gray \\
\hline A22 & $\begin{array}{l}\text { I often have trouble interpreting } \\
\text { messages from co-worker of the } \\
\text { opposite gender. }\end{array}$ & 4.26 & 3.73 & 4.89 & 0.00 & Supports Gray \\
\hline $\mathbf{A 2 3}$ & $\begin{array}{l}\text { I feel hurt and rejected when } \\
\text { co-worker of the opposite gender } \\
\text { grumble upon my request about } \\
\text { something. }\end{array}$ & 4.73 & 4.24 & 5.31 & 0.00 & Supports Gray \\
\hline
\end{tabular}

Table 3. T-tests from Part A (i.e. statements regarding the respondents themselves) where NO significant differences between male and female were found thus NOT supporting Gray's (1992) propositions

\begin{tabular}{|c|c|c|c|c|c|}
\hline Code & Statements & Mean & Male & Female & Sig \\
\hline A3 & I dislike being questioned just for the sake of connecting. & 5.36 & 5.52 & 5.06 & 0.13 \\
\hline A5 & I prefer independent activity rather than teamwork. & 4.62 & 4.05 & 4.85 & 0.18 \\
\hline A6 & $\begin{array}{l}\text { I am not concerned if someone at work doesn't like me, } \\
\text { as long as I have their respect. }\end{array}$ & 5.48 & 5.42 & 5.53 & 0.96 \\
\hline A7 & $\begin{array}{l}\text { I prefer to talk about work related matters rather than } \\
\text { personal matters. }\end{array}$ & 6.08 & 5.52 & 5.72 & 0.08 \\
\hline A8 & $\begin{array}{l}\text { If I'm confused I try to work it out myself rather than ask } \\
\text { for help or advice. }\end{array}$ & 4.96 & 4.82 & 5.15 & 0.23 \\
\hline A13 & $\begin{array}{l}\text { I find that talking about problems in the work place is not } \\
\text { worth the time it takes. }\end{array}$ & 5.75 & 5.83 & 5.85 & 0.43 \\
\hline A14 & $\begin{array}{l}\text { I'll go along with something I disagree with, rather than } \\
\text { make a stand. }\end{array}$ & 4.35 & 4.35 & 4.42 & 0.23 \\
\hline A15 & $\begin{array}{l}\text { I rely on gut feelings, more than logic, when making } \\
\text { difficult decisions. }\end{array}$ & 4.64 & 4.39 & 4.87 & 0.53 \\
\hline A16 & $\begin{array}{l}\text { I keep my negative thoughts and feelings to myself rather } \\
\text { than share them. }\end{array}$ & 5.22 & 5.47 & 5.05 & 0.29 \\
\hline A19 & I often ask clarifying questions to feel supported. & 6.00 & 6.31 & 5.74 & 0.05 \\
\hline
\end{tabular}


Table 4. T-tests from Part A (i.e. statements regarding the respondents themselves) where significant differences between male and female were found BUT IN THE DIRECTION OPPOSITE of Gray's (1992) propositions

\begin{tabular}{llllll}
\hline Code & Statements & Mean & Male & Female & Sig \\
\hline $\mathbf{A 4}$ & $\begin{array}{l}\text { If I have personal problems I have to } \\
\text { watch myself carefully so that they } \\
\text { don't interfere with my work. }\end{array}$ & 6.46 & $\mathbf{6 . 9 4}$ & 5.73 & 0.00 \\
\hline $\mathbf{A 9}$ & $\begin{array}{l}\text { Unresolved conflict makes me very } \\
\text { uncomfortable. }\end{array}$ & $\mathbf{6 . 6 5}$ & $\mathbf{6 . 9 0}$ & 6.06 & 0.00 \\
\hline $\mathbf{A 1 0}$ & $\begin{array}{l}\text { If someone appears to be upset I'll } \\
\text { find an opportunity to let them talk } \\
\text { about it with me. }\end{array}$ & 6.20 & $\mathbf{6 . 4 8}$ & 5.81 & 0.01 \\
\hline $\mathbf{A 1 1}$ & $\begin{array}{l}\text { If I am unsure of something at work, I } \\
\text { will seek for advice or assistance. }\end{array}$ & 6.96 & $\mathbf{7 . 8 1}$ & 6.06 & 0.00 \\
\hline $\mathbf{A 1 7}$ & $\begin{array}{l}\text { I appreciate reassurance at stressful } \\
\text { times. }\end{array}$ & 5.91 & $\mathbf{6 . 3 9}$ & 5.44 & 0.00 \\
\hline
\end{tabular}

